\title{
The Impact of Quality Management Practices on Manufacturing Performance: An Empirical Study Based on System Theory
}

\author{
Jie Liu \\ Nanjing University of Finance and Economics \\ Dejuan Zhuang ( $\sim$ ZhuangDejuan@outlook.com ) \\ Nanjing University of Finance and Economics \\ Wei Shen \\ Nanjing University of Finance and Economics
}

\section{Research Article}

Keywords: Quality management practices, Manufacturing performance, System theory

Posted Date: October 21st, 2021

DOI: https://doi.org/10.21203/rs.3.rs-985689/v1

License: (c) (i) This work is licensed under a Creative Commons Attribution 4.0 International License. Read Full License

Version of Record: A version of this preprint was published at Soft Computing on January 8th, 2022. See the published version at https://doi.org/10.1007/s00500-021-06606-3. 


\section{Abstract}

As one important part of core competitiveness of manufacturing enterprises, quality management practices have gradually received more attention. In many existing researches, quality management practices are regarded as a whole or categorized into two or four types of practice elements for discussions. There are less researches on the relationships among specific quality management practice elements and their impacts on manufacturing performance. This study analyzes quality management practices with the philosophical thinking of system theory, and deconstructs the mechanism of the mutual influences and synergies among various quality management practice elements and also their impacts on manufacturing performance, from an overall perspective through an empirical research. At last, a model of quality management practice synergies is built, as a theoretical support for manufacturing enterprises implementation of quality management practices.

\section{Introduction}

Quality management practices compose an organic comprehensive management system with complex interactions inside. Effective quality management should be implemented based on full exploration of the complementarity or synergy of different practice elements (Jiang and Su, 2013). Because not every quality management practice element directly affect performance, it is the synergy out of the mutual collaboration that has an impact on performance. However, the existing researches take quality management practices as a whole (Song et al., 2011), or roughly classify the quality management practice elements before exploring the relationships among them and their impacts on performance (Zeng et al., 2015; Wu, 2019; Sun et al., 2021). Few studies have deconstructed, from a holistic perspective, the internal influences and synergistic relationships among different quality management practice elements and their logical impacts on manufacturing performance. Wu (2019) found through a questionnaire survey of 397 companies in China that the synergy of quality management practices has a significant impact on the improvement of operational performance, and the synergy effect of quality management practices is greater than those of individual elements. Although that study focused on the synergy effect of quality management practice elements, it only included five elements of quality management practices (top management leadership, training, teamwork, internal process management, and external process management), and did not distinguish between different industries, which might lack of pertinence for guiding specific industries. Therefore, it is necessary to supplement the elements of quality management practice and conduct researches for specific industries.

System theory mainly studies the relationship of the inside elements with the system as a whole. Even the wholeness being the core attribute of a system, it is not equal to the system itself. In system theory, the wholeness of a system is not examined in isolation, but rather examined through its interrelationships with the elements, levels, structure, functions, and the environment (Chang, 2011). Based on system theory, quality management practices can be defined as "a set of interrelated or interacting elements of an organization to establish policies and objectives and processes to achieve these objectives with regard to quality" (according to ISO 9000:2015 Standard on Quality Management Systems-Fundamentals and Vocabulary). This definition regards quality management practices as a system that contains different practical elements. Existing researches often regard it as a whole, or categorize the different practical elements for research, but such categorization ignores the synergy effect of quality management practices as a system, and it also ignores the influences and effects among the different practice elements. To truly play the role of a quality management practice system, which means the whole is more than the sum of its parts, it is necessary to study the specific elements of quality management practices by exploring the theories of their interactions--the wholeness of quality management practice is studied through the interactions of the elements--and the impacts of them on performance.

Manufacturing companies in China have paid attention to the importance of quality management practices, and have implemented different quality management practices in quality management process to improve corporate performance and customer satisfaction. In order to better understand the implementation of quality management practices in China's manufacturing enterprises, and to provide a theory for implementing quality management practices in these enterprises, by combing domestic and foreign literature with the characteristics of China's manufacturing enterprises, this study constructs a model of quality management practice synergy based on eight elements (top management support, employee management, customer management, supplier management, training, information analysis, process management, and product design), through a questionnaire empirical research on manufacturing companies. Then, system theory is introduced to analyze and interpret the test results. Hence, an exploration is made on the synergy among different quality management practice elements and their impacts on manufacturing performance. The research conclusions would help manufacturing companies establish effective modes of quality management practices to improve the manufacturing performance and thereafter improve competitiveness.

\section{Literature Review}

2.1. Quality management practices 
Quality management is an overall management philosophy based on principles and practices that can improve corporate performance (Bouranta et al., 2017). It is characterized by joining the principles, practices, and technologies: the principles provide general guidelines, which are implemented in practices through support of technologies (Zeng et al., 2015). Enterprise managers should understand and apply quality philosophy to achieve performance improvement goals and competitive advantages through implementing quality management practices, so as to meet the challenges of new global competition (Boateng and Appiah, 2012). At present, most scholars agree that there are different elements of quality management practice, but they have not yet formed a unified view on the specific element content. This study sorts out the more widely used practice elements in the previous literature (see Table 1 for details) \combine the existing research results with the characteristics of the manufacturing company, and then construct a model of eight quality management practice elements, including top management support, employee management, customer management, supplier management, training, information analysis, process management and product design.

\begin{tabular}{|c|c|c|c|c|c|}
\hline Saraph et al.(1989) & $\begin{array}{l}\text { Flynn et al. } \\
\text { (1995) }\end{array}$ & Ahire et al.(1996) & MBNQA囚2002 & Kaynak(2003) & Zu et al.(2008) \\
\hline $\begin{array}{l}\text { The role of management } \\
\text { leadership and } \\
\text { quality policy }\end{array}$ & $\begin{array}{l}\text { Top } \\
\text { management } \\
\text { support }\end{array}$ & $\begin{array}{l}\text { Top management } \\
\text { commitment }\end{array}$ & Leadership & $\begin{array}{l}\text { Management } \\
\text { leadership }\end{array}$ & $\begin{array}{l}\text { Top } \\
\text { management } \\
\text { support }\end{array}$ \\
\hline $\begin{array}{l}\text { Role of the quality } \\
\text { department }\end{array}$ & & & Strategic planning & & \\
\hline Training & & Employee training & & Training & \\
\hline \multirow[t]{2}{*}{ Employee relations } & $\begin{array}{l}\text { Workforce } \\
\text { management }\end{array}$ & $\begin{array}{l}\text { Employee } \\
\text { empowerment }\end{array}$ & $\begin{array}{l}\text { Human resource } \\
\text { management }\end{array}$ & Employee relations & $\begin{array}{l}\text { Workforce } \\
\text { management }\end{array}$ \\
\hline & & $\begin{array}{l}\text { Employee } \\
\text { involvement }\end{array}$ & & & \\
\hline Quality data and reporting & $\begin{array}{l}\text { Statistic } \\
\text { control/feedback }\end{array}$ & $\begin{array}{l}\text { Internal quality } \\
\text { information }\end{array}$ & $\begin{array}{l}\text { Information and } \\
\text { analysis }\end{array}$ & $\begin{array}{l}\text { Quality data and } \\
\text { reporting }\end{array}$ & $\begin{array}{l}\text { Quality } \\
\text { information }\end{array}$ \\
\hline $\begin{array}{l}\text { Supplier quality } \\
\text { management }\end{array}$ & $\begin{array}{l}\text { Supplier } \\
\text { relationship }\end{array}$ & $\begin{array}{l}\text { Supplier quality } \\
\text { management }\end{array}$ & & $\begin{array}{l}\text { Supplier quality } \\
\text { management }\end{array}$ & $\begin{array}{l}\text { Supplier } \\
\text { relationship }\end{array}$ \\
\hline Product/service design & $\begin{array}{l}\text { Product design } \\
\text { process }\end{array}$ & $\begin{array}{l}\text { Design quality } \\
\text { management }\end{array}$ & & $\begin{array}{l}\text { Product/service } \\
\text { design }\end{array}$ & $\begin{array}{l}\text { Product/service } \\
\text { design }\end{array}$ \\
\hline \multirow[t]{3}{*}{ Process management } & $\begin{array}{l}\text { Process flow } \\
\text { management }\end{array}$ & $\begin{array}{l}\text { Statistical process } \\
\text { control }\end{array}$ & $\begin{array}{l}\text { Process } \\
\text { management }\end{array}$ & $\begin{array}{l}\text { Process } \\
\text { management }\end{array}$ & $\begin{array}{l}\text { Process } \\
\text { management }\end{array}$ \\
\hline & $\begin{array}{l}\text { Customer } \\
\text { relationship }\end{array}$ & Customer focus & $\begin{array}{l}\text { Customer and } \\
\text { market focus }\end{array}$ & & $\begin{array}{l}\text { Customer } \\
\text { relationship }\end{array}$ \\
\hline & Work attitude & Benchmarking & & & \\
\hline
\end{tabular}

\subsection{Researches on quality management practices-performance model}

The purpose of implementing quality management practices is to improve performance and thereby gain competitive advantages in the market (Kyobe, 2004). Therefore, the researches on quality management practices are mostly on quality management practices-performance model, which takes quality management practices as independent variables and performance as the dependent variable. The existing researches often regards quality management practices as a whole, or classify the quality management practices into multi-dimensions according to different principles to study from different angles. For example, Flynn et al. (1995) proposed to categorized quality management practices into infrastructure quality management practices and core quality management practices. The former ones focus on social-level behavior and communication, and the latter ones are of tools, technologies and methods orientation. Prajogo and Sohal (2004) believe that quality management practices can be divided into mechanical practice elements and organic ones, and tested the impact of these two types of practices on quality performance and innovation performance by empirical research. Kaynak and Hartley (2008)divided quality management practices into internal practices and external practices and measured the separate impacts of quality management practices on financial and market performance, quality performance, and inventory management performance respectively. There are also studies that divide quality management practices into hard practices and soft practices(Zeng et al., 2015). Recently researched and relatively widely used is the classifying quality management practices into exploitative and exploratory quality management practices (Zhang et al., 2012). A further classification on this basis was made by Wu and Zhang (2013) and Sun et al. (2021), who made further classification by the criteria of being 
internal and external practices, and hence quality management practices are divided into four more detailed practices. The literature on quality management practices-performance model research is sorted out as shown in Table 2. Most of the existing researches focus on research after classifying the multiple practices from different perspectives. Few studies have focused on the mutual influences and synergy among specific practice elements. In addition, previous studies have mostly taken corporate operational performance or quality performance as dependent variables. In recent years, some scholars have begun to pay attention to innovation performance and inventory management performance, but less attention has been paid to the impacts of quality management practices on manufacturing performance. Therefore, this study will explore the mutual influence and synergy among the elements of quality management practices and their influences on manufacturing performance. 
Table 2 Researches on quality management practices-performance model

\begin{tabular}{|c|c|c|c|c|}
\hline Author & Data Source & $\begin{array}{l}\text { Quality } \\
\text { management } \\
\text { practices }\end{array}$ & Performance & Main Findingss \\
\hline $\begin{array}{l}\text { Flynn et al. } \\
\text { (1995) }\end{array}$ & $\begin{array}{l}75 \text { American } \\
\text { manufacturing } \\
\text { companies }\end{array}$ & $\begin{array}{l}\text { Infrastructure } \\
\text { quality } \\
\text { management } \\
\text { practices } \\
\text { Core quality } \\
\text { management } \\
\text { practices }\end{array}$ & $\begin{array}{l}\text { Perceived } \\
\text { quality market } \\
\text { outcomes } \\
\text { Percent if } \\
\text { items that } \\
\text { pass final } \\
\text { inspection } \\
\text { without } \\
\text { requiring } \\
\text { rework } \\
\text { Competitive } \\
\text { advantage }\end{array}$ & $\begin{array}{l}\text { Infrastructure and core quality management practices significantly } \\
\text { impact quality and corporate performance. } \\
\text { Top management supports are critical to infrastructure and core } \\
\text { quality management practices. }\end{array}$ \\
\hline $\begin{array}{l}\text { Prajogo and } \\
\text { Sohal(2004)[ }\end{array}$ & $\begin{array}{l}194 \text { managers } \\
\text { in Australian } \\
\text { companies }\end{array}$ & $\begin{array}{l}\text { Mechanistic } \\
\text { quality } \\
\text { management } \\
\text { practices } \\
\text { Organic } \\
\text { quality } \\
\text { management } \\
\text { practices }\end{array}$ & $\begin{array}{l}\text { Quality } \\
\text { performance; } \\
\text { Innovation } \\
\text { performance }\end{array}$ & $\begin{array}{l}\text { Mechanistic quality management practices hanve a significant } \\
\text { relationship with quality performance. Organic quality } \\
\text { management practices hanve a significant relationship with } \\
\text { innovation performance. }\end{array}$ \\
\hline $\begin{array}{l}\text { Kaynak and } \\
\text { Hartley(2008) }\end{array}$ & $\begin{array}{l}424 \text { survey } \\
\text { replies from } \\
\text { American } \\
\text { manufacturing } \\
\text { companies }\end{array}$ & $\begin{array}{l}\text { Internal } \\
\text { quality } \\
\text { management } \\
\text { practices } \\
\text { External } \\
\text { quality } \\
\text { management } \\
\text { practices }\end{array}$ & $\begin{array}{l}\text { Financial and } \\
\text { market } \\
\text { performance } \\
\text { Quality } \\
\text { performance } \\
\\
\text { Inventory } \\
\text { management } \\
\text { performance }\end{array}$ & $\begin{array}{l}\text { Supplier quality management is positively related to inventory } \\
\text { management performance. Product/service design, process } \\
\text { management, inventory management performance are positively } \\
\text { related to quality performance. Quality performance is positively } \\
\text { related to financial and market performance. }\end{array}$ \\
\hline $\begin{array}{l}\text { Zhang et al. } \\
(2012)\end{array}$ & $\begin{array}{l}238 \\
\text { manufacturing } \\
\text { plants in three } \\
\text { industries } \\
\text { across eight } \\
\text { countries }\end{array}$ & $\begin{array}{l}\text { Exploration } \\
\text { quality } \\
\text { management } \\
\text { practices } \\
\text { Exploitation } \\
\text { quality } \\
\text { management } \\
\text { practices }\end{array}$ & $\begin{array}{l}\text { Manufacturing } \\
\text { performance }\end{array}$ & $\begin{array}{l}\text { In stable environments, exploitation quality management practices } \\
\text { have a more significant effect on manufacturing performance, } \\
\text { while in a dynamic environment, exploratory quality management } \\
\text { practices with an organic organizational structure have a more } \\
\text { significant effect on manufacturing performance. }\end{array}$ \\
\hline $\begin{array}{l}\text { Wu and } \\
\text { Zhang(2013) }\end{array}$ & $\begin{array}{l}397 \text { Chinese } \\
\text { companies }\end{array}$ & $\begin{array}{l}\text { Exploratory } \\
\text { oriented } \\
\text { external } \\
\text { practices } \\
\text { Exploitative } \\
\text { oriented } \\
\text { external } \\
\text { practices } \\
\text { Exploratory } \\
\text { oriented } \\
\text { internal } \\
\text { practices } \\
\text { Exploitative } \\
\text { oriented } \\
\text { internal } \\
\text { practices }\end{array}$ & $\begin{array}{l}\text { Operations } \\
\text { performance }\end{array}$ & $\begin{array}{l}\text { Exploration quality management practices have a significant } \\
\text { positive impact on the three operational performance dimensions } \\
\text { (cost, quality, and flexibility). Exploitation quality management } \\
\text { practices have a more significant effect on delivery, than } \\
\text { exploration quality management practices. }\end{array}$ \\
\hline $\begin{array}{l}\text { Zeng et al. } \\
(2015)\end{array}$ & $\begin{array}{l}283 \\
\text { companies } \\
\text { from eight } \\
\text { countries }\end{array}$ & $\begin{array}{l}\text { Hard quality } \\
\text { management } \\
\text { practices } \\
\text { Soft quality } \\
\text { management } \\
\text { practices }\end{array}$ & $\begin{array}{l}\text { Quality } \\
\text { performance } \\
\text { Innovation } \\
\text { performance }\end{array}$ & $\begin{array}{l}\text { Hard quality management directly and indirectly affects } \\
\text { innovation performance through its effect on quality performance. } \\
\text { Soft quality management has an indirect effect on innovation } \\
\text { performance through its effect on hard quality management. }\end{array}$ \\
\hline
\end{tabular}




\begin{tabular}{|c|c|c|c|c|}
\hline \multirow[t]{5}{*}{ Wu(2019) } & \multirow[t]{5}{*}{$\begin{array}{l}397 \text { Chinese } \\
\text { companies }\end{array}$} & $\begin{array}{l}\text { Top } \\
\text { management } \\
\text { leadership }\end{array}$ & \multirow[t]{5}{*}{$\begin{array}{l}\text { Operations } \\
\text { performance }\end{array}$} & \multirow[t]{5}{*}{$\begin{array}{l}\text { The synergistic effects across QM practices are substantial in } \\
\text { enhancing all operations performance dimensions whereas } \\
\text { individual effect varies for different performance goals. }\end{array}$} \\
\hline & & Training & & \\
\hline & & Teamwork & & \\
\hline & & $\begin{array}{l}\text { Internal } \\
\text { quality } \\
\text { practices }\end{array}$ & & \\
\hline & & $\begin{array}{l}\text { External } \\
\text { quality } \\
\text { practices }\end{array}$ & & \\
\hline \multirow[t]{4}{*}{$\begin{array}{l}\text { Sun et al. } \\
(2021)\end{array}$} & \multirow[t]{4}{*}{$\begin{array}{l}247 \text { Chinese } \\
\text { manufacturing } \\
\text { companies }\end{array}$} & $\begin{array}{l}\text { Exploratory } \\
\text { oriented } \\
\text { external } \\
\text { practices }\end{array}$ & \multirow{4}{*}{$\begin{array}{l}\text { Product } \\
\text { innovation } \\
\text { performance } \\
\text { Process } \\
\text { innovation } \\
\text { performance }\end{array}$} & \multirow[t]{4}{*}{$\begin{array}{l}\text { Quality management practices have a significant positive effect } \\
\text { on enterprise innovation performance. Compared with Exploitative } \\
\text { quality management practices, exploratory quality management } \\
\text { practices have a greater positive effect on enterprise innovation } \\
\text { performance. }\end{array}$} \\
\hline & & $\begin{array}{l}\text { Exploitative } \\
\text { oriented } \\
\text { external } \\
\text { practices }\end{array}$ & & \\
\hline & & $\begin{array}{l}\text { Exploratory } \\
\text { oriented } \\
\text { internal } \\
\text { practices }\end{array}$ & & \\
\hline & & $\begin{array}{l}\text { Exploitative } \\
\text { oriented } \\
\text { internal } \\
\text { practices }\end{array}$ & & \\
\hline
\end{tabular}

\subsection{System theory}

System theory was originally a theory developed by Bertalanffy (1972) on the basis of "the system theory of the organism". Bertalanffy (1972) believes that a system can be defined as a set of elements with interrelations among themselves and also with the environment. A system involves all features of the various entities that are usually handled by various disciplines. Therefore, system theory has an interdisciplinary nature.

The system theory unifies the previous theories, believing that an organization is an organic open system. In the context of environmental influences, all elements are interrelated and interdependent. The theory treats an organization as a whole, and assumes that synergy plays an important role (Dahlgaard-Park et al., 2018). Therefore, system theory can explain how the other departments in an organization are influenced when one department gets affected.

The elements involved in quality management practice and the complexity of their interrelationships requirements that quality management practice should not be considered as simple enterprise activities to investigate, but rather, it is systematic with coordination. System Theory can provide us with another perspective and other methods to analyze quality management practice. Based on the principles of System Theory, the practice of quality management can be regarded as a system that is composed of the elements of practice. These elements are interrelated and interdependent. A part of a system (containing multiple elements) constitutes a "subsystem", and the system as a whole can be understood through the interrelations between the subsystems (Dahlgaard-Park et al., 2018). In the past researches, many scholars categorized different quality management practice elements into different "subsystems". For example, Manzani et al. (2019) divide quality management practices into social subsystems and technical subsystems based on sociotechnical systems theory. Although this classification reflects the consciousness of subsystems of different practice elements, it does not deeply explore the interrelationship and interdependence of the elements as well as the subsystems.

\section{Hypotheses Development}

\subsection{Top management support}

Top management support is the most basic and critical element in the overall quality management practices. Flynn et al. (1995) believe that top management support can have an impact on other elements of quality management practices, and help encourage to organize and implement practices and behaviors that improve quality performance. In the highly competitive modern market, top management support plays an important role in implementing quality management, defining quality goals, executing quality plans, and ultimately involving 
employees in quality-related activities (Das et al., 2008). In addition, top management pays more attention to customer management, establishes and maintains friendly relationships with customers, so they can quickly obtain feedback on product quality and information of customer demands (Kharub and Sharma, 2015), which help improve customer satisfaction. In addition, top managers are also very concerned about supplier selection, requiring the suppliers to obtain quality certification, and they attach importance to long-term cooperative relationships with suppliers (Kaynak, 2003). In this way, efficiency of company procurement and production can be improved, and costs can be reduced. Based on the above, the following hypotheses can be developed:

H1a. Top management support has a significant positive impact on employee management;

H1b. Top management support has a significant positive impact on customer management;

H1c. Top management support has a significant positive impact on supplier management.

\subsection{Employee management and training}

Employee management is one of the very important practice elements in corporate quality management. It includes employee participation, employee training, and employee empowerment (Ahire et al., 1996). Employee participation in various activities, such as planning, decisionmaking and problem solving, is a sign of quality implementation (Prajogo and Brown, 2006). Kaynak (2003) believes that employee management includes various human resource management techniques, as well as training on principles and methods of quality management. Due to the importance of product quality to manufacturing companies, most of them will pay more attention to training of employees. And as quality management involves concepts and practices from various disciplines, it is required that all employees receive formal training on quality management concepts and tools, including training on statistics, trading, and other quality-related training (Ahire et al., 1996). Therefore, this study separates training from employee management as a separate quality management practice element, while employee management may have an impact on the trainings. When participating in quality management practices, employees can use the tools and techniques acquired through training to collect and analyze data and information, thereby enhancing their career potential (Kaynak, 2003; Dubey et al., 2015). Moreover, when practicing in corporate quality management, employees may understand themselves as internal customers and put pressure on suppliers by requiring them to maintain supply chain and carry out process innovation to shorten delivery cycle, and thus the company achieves control over the production process (Kharub and Sharma, 2020). Therefore, the following hypotheses can be put forward through the above researches:

H2a. Employee management has a significant positive impact on training;

H2b. Employee management has a significant positive impact on information analysis;

H2c. Employee management has a significant positive impact on process management.

H3. Training have a significant positive impact on information analysis.

\subsection{Customer Management}

In order to provide products and services that meet customer needs and expectations, companies attach great importance to customer management and customer relationship maintenance. Communication with key customers can help to quickly identify customer requirements, whether customer needs are met, and the improvements needed in the future (Flynn et al., 1994). Customer management can promote collecting product \& service quality information, and running of customer satisfaction surveys. When business managers or employees contact customers, they can directly obtain information and feedback on product and service quality, which are to be used in quality decisions to improve customer satisfaction (Albers Mohrman et al., 1995). Therefore, the following hypothesis can be made:

H4. Customer management has a significant positive impact on information analysis.

\subsection{Supplier management}

Interdependent and cooperative relations have been established between enterprises and suppliers, as well as links of information exchange between them. Suppliers can contribute to product design process by joining the corporate product design team. When the supplier participates in the product design process, it can provide information for production process standardization and materials and parts that are expected (Flynn et al., 1995; Kaynak, 2003), thus helping companies with more efficiency of process management and product design.

Moreover, through supplier management, high-quality raw materials and parts can be delivered in time, sufficient and supply in time can be ensured, thus the controllability of process management and the reliability of compliant products can be improved (Kaynak, 2003; Negron, 2020). Therefore, this research proposes the following hypotheses:

H5a. Supplier management has a significant positive impact on process management; 
H5b. Supplier management has a significant positive impact on product design.

\subsection{Information analysis}

As for information analysis, technologies and tools of quality, as well as modern information technologies are used to collect and analyze various data and information about quality, for quality improvement decision(Jiang and Su, 2013). Flynn et al.'s (1994) research on quality management emphasized the importance of the availability, accuracy and timeliness of quality information. Data and information collection and analysis helps business managers and employees to timely identify and solve supply problems of materials and parts and feedback to the suppliers. In addition, product design requires extensive quality related information from operational links of procurement, marketing, manufacturing, design, and customers and the suppliers. Besides, process management also relies on employees for collecting and analyzing quality data (such as rework, scrapping, and warranty costs) at end points. The collection and analysis of quality information helps companies to strictly control quality in product design and process management, and to solve problems quickly (Flynn et al., 1994; Kaynak, 2003). Therefore, effective use of information about quality can provide accurate and timely information about product quality and the production process to promote product design, process management, and supplier management. Based on this, the following hypotheses can be made:

H6a. Information analysis has a significant positive impact on supplier management;

H6b. Information analysis has a significant positive impact on product design;

H6c. Information analysis has a significant positive impact on process management.

\subsection{Process management}

Process management uses fool-proof design to reduce process variation and improve relevant manufacturing technology (Flynn et al., 1995). Process management also reduce rework and waste by immediately identifying and correcting quality problems (Ahire and Dreyfus, 2000). Meanwhile, enterprises control production process by statistical process control and other inspection procedures. Effective process management can reduce process variation and have a direct impact on performance (Kaynak, 2003). At the same time, as process variation decreases, rates of quality consistency and delivery punctuality increase accordingly. Process control also involves using data and information to reduce process duplication and process variation, eliminate production interruptions, and improve reliability, thereby achieving a stable production process and superior quality (Wu, 2019).Through meta-analysis of related research on quality management practices, Nair (2006) found that process management can improve business performance. Therefore, this research proposes the following hypothesis:

H7. Process management has a significant positive impact on manufacturing performance.

\subsection{Product design}

On one hand, product design affects product reliability, product characteristics and maintainability, and incorporates customer needs and expectations, so it can reduce process complexity, process variation, and quality problems, thereby promoting enterprise process management. In turn, it has an impact on performance (Kaynak, 2003). On the other hand, product design quality will also affect quality performance, and enterprises with high quality performance will invest more energy in product design management. Enterprises can speed up new product development by optimizing product design process, and accelerate product production process by simplifying product design and standardizing components. Better product design and faster new product launches won over and retained customers (Ahire and Dreyfus,2000). Therefore, the following hypotheses can be made:

H8a. Product design has a significant positive impact on process management;

H8b. Product design has a significant positive impact on manufacturing performance.

In summary, the research puts forward a theoretical model of the synergy between quality management practice elements and their impact on manufacturing performance, as shown in Fig. 1.

\section{Research Design}

\subsection{Questionnaire design}

Based on the elements of quality management practice summarized by Flynn et al. (1995) and Kaynak (2003), and combined with the characteristics of China's manufacturing enterprises, this study choses a total of eight quality management practice elements, including top 
management support, employee management, customer management, supplier management, training, information analysis, process management and product design. A model is built of the synergistic relationship among the eight elements of quality management practices and their impact paths on performance. The scales of top management support and customer management comes from the researches of Addis (2019) and Negron (2020). The employee management scale is based on the researches of Patyal et al. (2019) and Sciarelli et al. (2020), and another item of "the communication between the management and the employees" is added to measure the importance of communication in quality management practices. The supplier management scale is derived from the research of Patyal and Koilakuntla (2017) and Wu (2019). The training scale draws on the research of Patyal and Koilakuntla (2017), Akanmu et al. (2020) and Negron (2020). The information analysis scale draws on the research of Patyal and Koilakuntla (2017). The product design scale refers to the researches of Patyal and Koilakuntla (2017) and Akanmu et al. (2020). The process management scale is based on the researches of Patyal and Koilakuntla (2017) and Addis (2019), and another item of "Fool proof" is added by the author of this study because its application of is very extensive in process management of manufacturing enterprises. Each scale uses the 7-point Likert scale, and the answer ranges from very unimportant to very important.

Ward et al. (1998) determined by factor analysis that manufacturing performance is composed of four dimensions: quality, cost, time, and flexibility. This study combines the researches of Ward et al. (1998), Naor et al. (2008) and Zhang et al. (2012) to measure and evaluate the quality, cost, delivery and flexibility dimensions of manufacturing performance through 10 items. The quality dimension is measured by three items: quality consistency, product return rate, and quality cost. The cost dimension is measured by inventory turnover rate, and unit cost. The delivery dimension is measured by the delivery punctuality rate, and the delivery time. And the flexibility dimension is measured by the number of products, the product mix, and variation in the production process. The manufacturing performance scale uses a 7-point Likert scale, and each interviewee needs to respond based on the improvement of the company's manufacturing performance. The responses range from very disagree to very agree. The number of all variable items and their sources are shown in Table 3.

Table 3

Variables, scale sources and reliability test

\begin{tabular}{|c|c|c|c|c|c|c|}
\hline Variables & $\begin{array}{l}\text { No. of } \\
\text { Items }\end{array}$ & Scale Sources & Cronbach'a & CR & $\begin{array}{l}\text { AVE's } \\
\text { square } \\
\text { foot }\end{array}$ & $\begin{array}{l}\text { KMO } \\
\text { Test }\end{array}$ \\
\hline $\begin{array}{l}\text { Top management } \\
\text { support }\end{array}$ & 7 & Addis, 2019; Negron, 2020 & 0.851 & 0.890 & 0.733 & 0.782 \\
\hline $\begin{array}{l}\text { Employee } \\
\text { management }\end{array}$ & 4 & Patyal et al., 2019; Sciarelli et al., 2020 & 0.880 & 0.918 & 0.858 & 0.811 \\
\hline $\begin{array}{l}\text { Customer } \\
\text { management }\end{array}$ & 5 & Addis, 2019; Negron, 2020 & 0.919 & 0.939 & 0.870 & 0.861 \\
\hline Supplier management & 9 & Patyal and Koilakuntla, 2017; Wu, 2019 & 0.925 & 0.940 & 0.799 & 0.909 \\
\hline Training & 6 & $\begin{array}{l}\text { Akanmu et al., 2020; Negron, 2020; Patyal and } \\
\text { Koilakuntla, } 2017\end{array}$ & 0.859 & 0.904 & 0.783 & 0.770 \\
\hline Information analysis & 5 & Patyal and Koilakuntla, 2017 & 0.890 & 0.919 & 0.834 & 0.845 \\
\hline Product design & 6 & Patyal and Koilakuntla, 2017; Akanmu et al., 2020 & 0.848 & 0.886 & 0.756 & 0.790 \\
\hline Process management & 4 & Patyal and Koilakuntla, 2017; Addis, 2019 & 0.824 & 0.884 & 0.811 & 0.789 \\
\hline $\begin{array}{l}\text { Manufacturing } \\
\text { performance }\end{array}$ & 10 & Ward et al., 1998; Naor et al., 2008; Zhang et al., 2012 & 0.945 & 0.956 & 0.828 & 0.893 \\
\hline
\end{tabular}

\subsection{Data collection}

A questionnaire survey was made to collect data, mainly through field research and also through e-mails. Questionnaires were distributed to middle and top management or the person in charge of quality management in 210 domestic manufacturing companies. A total of 157 questionnaires were collected from the sample companies. In terms of industry, the survey covers manufacturing companies in food, plastic, rubber, textile fiber, construction, electrical, chemical, electronics, communications, biochemical, electrical and cable, and mechanical processing industries. Excluding invalid questionnaires that are incomplete, consistent in options, or incorrectly filled out, 123 valid questionnaires were finally obtained, with an effective recovery rate of $78.34 \%$.

\subsection{Reliability and validity test}

In this study, SPSS23.0 statistical software was used for data analysis, and the data reliability and validity test results are analyzed as follows. 


\subsubsection{Reliability analysis}

Cronbach's a as used to test the reliability of each scale. If the Cronbach's a is higher than 0.8 , the reliability is high; if the Cronbach's a is between 0.7 and 0.8 , the reliability is good; if the Cronbach's a is between 0.6 and 0.7 , the reliability is acceptable; if the Cronbach's a is less than 0.6 , the reliability is not good. The specific results of the reliability test are shown in Table 3 . The reliability coefficient values of the eight quality management practice elements and manufacturing performance are all greater than 0.7 , and each composite reliability (CR) is higher than 0.8 , indicating that the internal consistency of the scales are high. It shows that the reliability of the research data is of good quality and can be used for further analysis.

\subsubsection{Validity analysis}

Validity research is used to analyze whether the scale items are reasonable and meaningful. This study uses content validity and structure validity to test the validity. The items in this research are all derived from the maturity scales in the relevant literature, which have been repeatedly verified and widely accepted, so they have good content validity. Structure validity is tested by convergent validity and discriminative validity. At first this study conducted KMO test and Bartlett sphere test for each variable to observe whether the data is suitable for factor analysis. The specific results are shown in Table 3. The KMO value corresponding to each variable is greater than 0.7, and Bartlett's tests of sphericity are all Significant, meaning that the data is valid and suitable for factor analysis. Secondly, the convergent validity was tested by factor loading and AVE value. The result of factor analysis showed that the factor loading value of each variable item is greater than 0.5 , and the cumulative explanatory variation of each variable exceeds $50 \%$, indicating that the convergent validity of the scale of this study was good. Finally, this study compares the AVE's square root of each variable with the correlation coefficient between variables, and the square root of AVE between each variable is greater than the correlation coefficient between variables (see Table 4 for specific results). Therefore, the discriminative validity of the scale is good.

\section{Data Analysis And Hypothesis Testing 5.1. Correlation analysis}

A Pearson correlation analysis was conducted on top management support, employee management, customer management, supplier management, training, information analysis, process management, product design, and manufacturing performance. The standard deviation, mean and correlation coefficient between the variables are shown in Table 4. It can be seen that the correlation between the various elements of the quality management practice and the manufacturing performance is significant, and regression analysis can be performed.

Table 4

Mean, SD and correlation analysis

\begin{tabular}{|c|c|c|c|c|c|c|c|c|c|c|c|}
\hline Variables & Mean & SD & 1 & 2 & 3 & 4 & 5 & 6 & 7 & 8 & 9 \\
\hline $\begin{array}{l}\text { 1.Top management } \\
\text { support }\end{array}$ & 5.80 & 0.709 & 0.733 & & & & & & & & \\
\hline $\begin{array}{l}\text { 2. Employee } \\
\text { management }\end{array}$ & 5.48 & 0.798 & $0.537 * \star$ & 0.858 & & & & & & & \\
\hline $\begin{array}{l}\text { 3. Customer } \\
\text { management }\end{array}$ & 5.78 & 0.863 & $0.593^{\star \star}$ & $0.683^{\star *}$ & 0.870 & & & & & & \\
\hline $\begin{array}{l}\text { 4. Supplier } \\
\text { management }\end{array}$ & 5.37 & 0.846 & $0.541 * \star$ & $0.750 * \star$ & $0.640 * \star$ & 0.799 & & & & & \\
\hline 5. Training & 5.28 & 0.843 & $0.638 * *$ & 0.586 ** & $0.400 * *$ & $0.566^{\star \star}$ & 0.783 & & & & \\
\hline $\begin{array}{l}\text { 6. Information } \\
\text { analysis }\end{array}$ & 5.46 & 0.777 & $0.591^{\star \star}$ & $0.766^{\star \star}$ & $0.693^{\star \star}$ & $0.762^{\star \star}$ & $0.595^{\star \star}$ & 0.834 & & & \\
\hline 7. Product design & 5.61 & 0.727 & $0.689 * \star$ & 0.650 ** & $0.598^{\star \star}$ & $0.705^{\star \star}$ & $0.599 \star \star$ & $0.669 * \star$ & 0.756 & & \\
\hline $\begin{array}{l}\text { 8. Process } \\
\text { management }\end{array}$ & 5.35 & 0.792 & $0.500 * \star$ & $0.654^{\star \star}$ & $0.663^{\star \star}$ & $0.719 * \star$ & $0.592^{\star \star}$ & $0.793^{\star \star}$ & 0.601 ** & 0.811 & \\
\hline 9. Manufacturing & 5.17 & 0.891 & $0.452^{\star \star}$ & $0.739 \star \star$ & $0.567 * \star$ & $0.674^{\star *}$ & $0.477 * \star$ & $0.608 * \star$ & $0.555^{\star \star}$ & $0.558 * \star$ & 0.828 \\
\hline
\end{tabular}
performance

Note: The number on the diagonal is the square root of AVE; ** At the level of 0.01 (two-tailed), the correlation is significant. 
The hypotheses testing results are shown in Table 5. It can be concluded that the hypotheses proposed in this study are all valid. This shows that the various elements of quality management practice have mutual impacts, and the synergy of these practice elements has a significant impact on manufacturing performance.

As the starting point and source of all practice elements, top management support plays a fundamental and critical role in quality management activities. Through defining quality objectives, executing quality plans, allocating corporate resources, and promoting employees' participation in quality management practices, top management support has significant positive effects on employee management $(\beta=0.605, p<0.01)$, customer management $(\beta=0.722, p<0.01)$ and supplier management $(\beta=0.646, p<0.01)$. The top management support employees to participate in quality decision-making and plan proposal, and provides certain resources to support both the management and the employees to participate in quality-related training, which can promote employees to actively participate in training and pay attention to the collection, analysis and application of quality information. In addition, quality improvement success in process management depends on the effectiveness of how the quality management tools are actually used, which is ensured by the management that provide employees with rigorous training and encourage them to use these tools at work (Ahire and Dreyfus, 2000). The regression results of this study also support this conclusion. Employee management has significant impacts on training $(\beta=0.618, p<0.01)$, information analysis $(\beta=0.745, p<0.01)$, and process management $(\beta=0.654, p<0.01) . H 3$ is also supported. Training have a significant positive impact on information analysis $(\beta=0.549, p<0.01)$. Companies are committed to establishing and maintaining customer relationships, maintaining timely and effective communication with customers, which help the companies to collect and analyze quality related information ( $\beta=0.624$, $\mathrm{p}<0.01$ ) to meet customer needs and improve customer satisfaction. Manufacturers choose suppliers based on quality considerations rather than price or other aspects. They attach great importance to the implementation of quality control measures for the suppliers, to understand their quality and specifications, to consider the suppliers during product design process, and to promptly notify the supplier for proper responds when there is a change in product design and production process. Therefore, supplier management of manufacturing enterprises has a significant positive impact on product design $(\beta=0.605, p<0.01)$ and process management $(\beta=0.672, p<0.01)$. In the model constructed in this research, information analysis is at the core position. This practice element requires companies to systematically collect data according to the problem-solving cycle to identify the key problems, analyze their root causes, and propose solutions (Hackman and Wageman, 1995). Accurate and timely quality information can directly promote supplier management $(\beta=0.829, p<0.01)$, product design $(\beta=$ $0.625, p<0.01)$ and process management $(\beta=0.808, p<0.01)$. Process management helps companies establish a stable production process, which not only improves product quality, but also reduces the need for rework, scrap and buffer inventory, thereby improving manufacturing performance $(\beta=0.628, p<0.01)$. Focusing on product design can help companies promote process management $(\beta=0.655$, $p<0.01)$ and improve manufacturing performance $(\beta=0.681, p<0.01)$. Previous research also recognized the synergy between product design and process management (Ahire and Dreyfus, 2000). The research results also support the view of Kumar et al. (2009) that product design directly affects product quality and performance, while the fool-proof design of equipment improves productivity and reduces problems in the process management. 
Table 5

Results of regression analysis

\begin{tabular}{|c|c|c|c|c|c|c|c|c|}
\hline \multirow{2}{*}{$\begin{array}{l}\text { Independent } \\
\text { variables }\end{array}$} & \multicolumn{8}{|c|}{ Dependent variables } \\
\hline & $\begin{array}{l}\text { Employee } \\
\text { management }\end{array}$ & $\begin{array}{l}\text { Customer } \\
\text { management }\end{array}$ & $\begin{array}{l}\text { Supplier } \\
\text { management }\end{array}$ & Training & $\begin{array}{l}\text { Information } \\
\text { analysis }\end{array}$ & $\begin{array}{l}\text { Product } \\
\text { design }\end{array}$ & $\begin{array}{l}\text { Process } \\
\text { management }\end{array}$ & $\begin{array}{l}\text { Manufacturing } \\
\text { performance }\end{array}$ \\
\hline $\begin{array}{l}\text { Top } \\
\text { management } \\
\text { support }\end{array}$ & $0.605^{\star \star \star}$ & 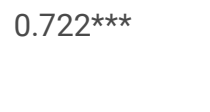 & $0.646 * \star \star$ & & & & & \\
\hline $\begin{array}{l}\text { Employee } \\
\text { management }\end{array}$ & & & & $0.618 * \star \star$ & $0.745^{\star \star \star}$ & & $0.654 * \star \star$ & \\
\hline Training & & & & & $0.549 * \star \star$ & & & \\
\hline $\begin{array}{l}\text { Customer } \\
\text { management }\end{array}$ & & & & & $0.624^{\star * *}$ & & & \\
\hline $\begin{array}{l}\text { Supplier } \\
\text { management }\end{array}$ & & & & & & $0.605^{\star \star \star}$ & $0.672^{\star \star *}$ & \\
\hline $\begin{array}{l}\text { Information } \\
\text { analysis }\end{array}$ & & & $0.829 * * \star$ & & & $0.625^{\star \star \star}$ & $0.808^{\star * *}$ & \\
\hline $\begin{array}{l}\text { Product } \\
\text { design }\end{array}$ & & & & & & & $0.655^{\star \star \star}$ & $0.681^{\star \star \star}$ \\
\hline $\begin{array}{l}\text { Process } \\
\text { management }\end{array}$ & & & & & & & & $0.628^{\star \star \star}$ \\
\hline Note: ${ }^{*} p<0.1 ;$ & $<0.05 \rrbracket^{\star \star *} p$ & & & & & & & \\
\hline
\end{tabular}

\subsection{Quality management practices based on system theory}

System theory believes that an organization is an organic open system, and all elements are interrelated and interdependent in the context of environmental impact (Dahlgaard-Park et al., 2018). Based on this, the practice elements in the quality management practice system are interrelated and affect each other. With the continuous deepening of corporate quality management practices, quality management presents the characteristics of complexity, dynamics and systematization, which requires companies to formulate quality management strategies and plans from the perspective of system theory to achieve more efficient quality management practices.

According to system theory, the relationship between the whole and the parts is the core issue. Only grasping the wholeness of things cannot lead to the grasp of the system. Only through organically combining the whole with the parts can we truly understand a system (Chang, 2011), and it is necessary to grasp both the main parts and the minor parts in order to produce the effect of "the whole is more than the sum of its parts". Therefore, the implementation of quality management practices in an enterprise must be overall planned while being coordinately managed. It is necessary to grasp important and key quality practices as well as other subsidiary quality practices. In the process of implementing quality management practices in an enterprise, it is necessary to consider and evaluate quality issues from the perspective of the enterprise as a whole, coordinate and integrate all the relationships between the practice elements. Only when the overall practice activities and the elements match, can quality management implementation be guaranteed, and the manufacturing performance and market competitiveness of the enterprise be improved.

By constructing a theoretical model, followed by an empirical research of it, on the synergies among the elements of quality management practice and their impacts on manufacturing performance, and jointly by the principles of system theory, we propose a synergistic model of quality management practices as shown in Fig. 2. In this model, four practice elements as of top management support, information analysis, product design, and process management form a subsystem that is supportive to the whole system. Among them, the impacts of top management support and information analysis are most critical and they even determine the goals, strategies, plans, and execution of corporate quality management practices. Research by Akanmu et al. (2020) also supports this view. As an internal practices subsystem, employee management and training have significant impacts on enterprise quality information analysis and continuous improvement of process management, while customer management and supplier management as an external practices subsystem can improve the authenticity and effectiveness of collecting quality information, and promote the reliability and manufacturability of product design, reduce process variance and process complexity. At the same time, these two subsystems, and the four practice elements in them, are influenced and restricted with one another. They both play subsidiary roles in the overall system. Therefore, companies must have an overall plan of quality management while coordinately manage the practice elements in the supportive practices subsystem as well as the two subsidiary practices 
subsystems, in order to effectively improve manufacturing performance. All in all, a synergistic system of quality management practice can be created that strengthens the synergistic relationship among the various elements of quality management practice, and plays both supportive and subsidiary roles for the entire quality management system.

\section{Research Conclusions And Prospects \\ 6.1. Research conclusions and enlightenment}

The previous literatures of quality management practices mostly focus on the overall quality management practices, or categorize quality management practices into multi-dimension of practice elements according to different principles and then conducts research. We constructed a theoretical model of the interactions between the various elements of quality management practice and their impacts on manufacturing performance, and made a questionnaire survey. The empirical research found that there are synergistic relationships among the eight quality management practice elements (top management support, employee management, customer management, supplier management, training, information analysis, process management, product design), and that process management and product design have a direct impact on manufacturing performance. And then, we used principles of system theory to explain the model, and finally come up with a new synergistic model of quality management practice that includes a supportive practices subsystem and two subsidiary practices subsystems, as a theory provided for manufacturing companies to implement quality management practices and improve manufacturing performance.

Based on the principles of system theory, enterprises should make overall planning and coordinated management in the process of quality management practices. They should not only pay attention to the supportive practices subsystem, but also allocate resources reasonably and pay attention to the important influences and roles of the subsidiary practices subsystems. Therefore, it is recommended that companies adopt quality management practice elements with clear goals and follow the principles and methods specified by the practice elements in a consistent manner until the goals are achieved, rather than just implementing multiple practice elements at the same time, because this will not only confuse the implementer's understanding of the different methods prescribed by these practice elements but also cause duplication of work (Kumar et al., 2018). In a quality-centered development strategy with stressed points for perfection, it is very important to have strong quality leadership (Flynn et al., 1995). Through active quality leadership, top management support has significant impacts on employee management, customer management and supply management. If a leadership failure that involves several top managers appears at the system level, the system may fail (Dahlgaard-Park et al., 2018). A system can only succeed if the managers collaborate within multiple subsystems, or even collaborate across multiple subsystems. In addition, companies should also pay attention to the important role of information analysis and attach importance to the collection and use of quality information, because the effectiveness of such information can provide accurate and timely information about the quality and features of a product to promote supplier relationships, product design and process management, thereby affecting manufacturing performance. Finally, apart from the supportive practice activities, companies should also consider the subsidiary roles of employee management, training, customer management and supplier management. More resources should be provided to do well in employee management and training to improve their professional skills and quality awareness, and companies should establish and maintain close relationships with customers and suppliers. Communication efficiency should be improved, and a win-win cooperation should be made with the suppliers.

\subsection{Research limitations and prospects}

Due to the small sample size, we chose regression analysis as a research method, supplemented by correlation analysis. However, this research method is relatively simple. In the future, the sample size can be expanded and the structural equation model can be used to analyze the paths of quality management practice elements. At the same time, the causal relationship between multiple dependent variables and independent variables can be tested, and the deviation can be reduced by considering measurement errors.

This research focuses on the synergistic relationship among the eight elements of quality management practice, and does not discuss its prevariables. In fact, exploring the pre-variables of quality management practices can help companies understand and implement quality management practices more deeply, while being conducive to theoretical research of quality management practices. For example, some studies believe that the elements of information analysis can be measured by five variables: performance measuring and analyzing, information management, benchmarks, the use of information technology, and tools of quality management (Sila and Ebrahimpour, 2005). In the future, the pre-variables of other elements can be measured and researched. Other industries can be selected, and other quality management practice elements can be added or replaced to continue in-depth exploration.

This study did not consider the influence of internal and external environmental factors in the enterprises when discussing the synergies among quality management practice elements and their impacts on manufacturing performance. Even for a same quality management 
practice element, different environmental factors such as company size, corporate culture, national culture, policies, market competition intensity, etc., may lead to a different conclusion. Therefore, it is necessary to further explore the synergistic relationships among the quality management practice elements and their impacts on performance, under the influence of different environmental factors.

\section{Declarations}

\section{Funding}

This work was supported by National Social Science Foundation of China [grant number 20BGL106].

\section{Authors' contributions}

Jie Liu is the supervisor of the paper and is responsible for funding acquisition, investigation, data collection, methodology, supervision and writing - review \& editing. Dejuan Zhuang is responsible for data curation, data analysis and the writing of the paper. Wei Shen is responsible for writing - review \& editing, visualization.

\section{Informed consent}

The manuscript was not submitted to multiple journals for simultaneous consideration. and the submitted works are original and have not been published elsewhere in any form or language (part or all).

\section{Conflict of interest}

The authors declare that they have no known competing financial interests or personal relationships that could have appeared to influence the work reported in this paper.

\section{References}

1. Addis S. An exploration of quality management practices in the manufacturing industry of Ethiopia. The TQM Journal, 2019, 32 (1):127142.

2. Ahire S. L., Dreyfus P. The impact of design management and process management on quality: an empirical investigation. Journal of Operations Management, 2000, 18 (5):549-575.

3. Ahire S. L., Golhar D. Y., Waller M. A. Development and Validation of TQM Implementation Constructs. Decision sciences, 1996, 27 (1):2356.

4. Akanmu M. D., Hassan M. G., Bahaudin A. Y. B. A preliminary analysis modeling of the relationship between quality management practices and sustainable performance. The Quality management journal, 2020, 27 (1):37-61.

5. Albers Mohrman S., Tenkasi R. V., Lawler E. E., et al. Total quality management: practice and outcomes in the largest US firms. Employee relations, 1995, 17 (3):26-41.

6. Bertalanffy L. V. The History and Status of General Systems Theory. The Academy of Management Journal, 1972,15 (4):407-426.

7. Boateng Okrah E., Appiah Fening F. TQM implementation: a case of a mining company in Ghana. Benchmarking: An International Journal, 2012, 19 (6):743-759.

8. Bouranta N., Psomas E. L., Pantouvakis A. Identifying the critical determinants of TQM and their impact on company performance. The TQM Journal, 2017, 29 (1): 147-166.

9. Chang S. From Classical System in the Case of Modern System Theory. Journal of Systems Science, 2011,19 (03):1-4.

10. Criteria for Performance Excellence, 2002. Baldrige National Quality Program. Department of Commerce, National Institute of Standards and Technology, Technology Administration, Gaithersburg, MD, USA.

11. Dahlgaard-Park S. M., Reyes L., Chen C. The evolution and convergence of total quality management and management theories. Total quality management \& business excellence, 2018, 29 (9-10):1108-1128.

12. Das A., Paul H., Swierczek F. W. Developing and validating total quality management (TQM) constructs in the context of Thailand's manufacturing industry. Benchmarking: An International Journal, 2008, 15 (1):52-72.

13. Dubey R., Gunasekaran A., Samar Ali S. Exploring the relationship between leadership, operational practices, institutional pressures and environmental performance: A framework for green supply chain. International Journal of Production Economics, 2015, 160:120-132.

14. Flynn B. B., Schroeder R. G., Sakakibara S. A framework for quality management research and an associated measurement instrument. Journal of Operations Management, 1994, 11 (4):339-366. 
15. Flynn B. B., Schroeder R. G., Sakakibara S. The Impact of Quality Management Practices on Performance and Competitive Advantage. Decision sciences, 1995, 26 (5):659-691.

16. Hackman R., Wageman R. Total Quality Management: Empirical, Conceptual, and Practical Issues. Administrative Science Quarterly, 1995, 40 (2):309-342.

17. Jiang P., Su Q. Review and prospect of research on the relationship model between quality management and enterprise performance. Foreign Economic \& Management, 2013, 35 (01):47-54.

18. Kaynak H. The relationship between total quality management practices and their effects on firm performance. Journal of Operations Management, 2003, 21 (4):405-435.

19. Kaynak H., Hartley J. L. A replication and extension of quality management into the supply chain. Journal of operations management, 2008, 26 (4):468-489.

20. Kharub M., Sharma R. K. An integrated structural model of QMPs, QMS and firm's performance for competitive positioning in MSMEs. Total Quality Management \& Business Excellence, 2020, 31 (3-4):312-341.

21. Kharub M., Sharma R. K. Investigating the role of CSF's for successful implementation of quality management practices in MSMEs. International Journal of System Assurance Engineering and Management, 2016, 7 (S1):247-273.

22. Kumar P., Maiti J., Gunasekaran A. Impact of Quality Management Systems on Firm Performance. International Journal of Quality \& Reliability Management, 2018, 35 (5):1034-1059.

23. Kumar U., Kumar V., de Grosbois D., Choisne F. Continuous improvement of performance measurement by TQM adopters. Total Quality Management, 2009, 20 (6):603-616.

24. Kyobe M. E. Investigating the Strategic Utilization of IT Resources in the Small and Medium-Sized Firms of the Eastern Free State Province. International Small Business Journal: Researching Entrepreneurship, 2004, 22 (2):131-158.

25. Manzani Y. E., Sidmou M. L., Cegarra J. Does IS0 9001 quality management system support product innovation? An analysis from the sociotechnical systems theory. International Journal of Quality \& Reliability Management, 2019, 36 (6):951-982.

26. Nair A. Meta-analysis of the relationship between quality management practices and firm performance-implications for quality management theory development. Journal of Operations Management, 2006, 24 (6):948-975.

27. Naor M., Goldstein S. M., Linderman K. W., et al. The Role of Culture as Driver of Quality Management and Performance: Infrastructure Versus Core Quality Practices. Decision sciences, 2008, 39 (4):671-702.

28. Negron L. A. Relationship between quality management practices, performance and maturity quality management, a contingency approach. The Quality management journal, 2020, 27 (4):215-228.

29. Patyal V. S., Ambekar S., Prakash A. Organizational culture and total quality management practices in Indian construction industry. International Journal of Productivity and Performance Management, 2019, 69 (5):895-913.

30. Patyal V. S., Koilakuntla M. The impact of quality management practices on performance: an empirical study. Benchmarking: An International Journal, 2017, 24 (2):511-535.

31. Prajogo D. I., Brown A. Approaches to adopting quality in SMEs and the impact on quality management practices and performance. Total quality management \& business excellence, 2006, 17 (5):555-566.

32. Prajogo D. I., Sohal A. S. The multidimensionality of TQM practices in determining quality and innovation performance - an empirical examination. Technovation, 2004, 24 (6):443-453.

33. Saraph, J.V ., Benson, G.P . Schroeder, R.G.An instrument for measuring the critical factors of quality management. Decision Sciences, 1989, 20 (4):810-829.

34. Sciarelli M., Gheith M. H., Tani M. The relationship between soft and hard quality management practices, innovation and organizational performance in higher education. The TQM Journal, 2020, 32 (6):1349-1372.

35. Sila I., Ebrahimpour M. Critical linkages among TQM factors and business results. International Journal of Operations \& Production Management, 2005, 25 (11):1123-1155.

36. Song Y., Su Q., Jiang P. The effect of relationship quality on quality management practice and performance. Science Research Management, 2011, 32(04): 69-75+85.

37. Sun W., Zhang L., Lin Z. Research on the Impact of Quality Management Practice on Enterprise Innovation Performance--The Moderating Effect of Market Competition Intensity. Science \& Technology Progress and Policy, 2021, 38 (07): 95-104.

38. Ward P. T., McCreery J. K., Ritzman L. P., et al. Competitive Priorities in Operations Management. Decision sciences, 1998, 29 (4):10351046.

39. Wu S. J. Assessing the individual and synergistic effects of quality management practices on operations performance. International Journal of Productivity and Performance Management, 2019, 69 (2): 297-320.

Page $15 / 17$ 
40. Wu S. J., Zhang D. Analyzing the effectiveness of quality management practices in China. International Journal of Production Economics, 2013, 144 (1):281-289.

41. Zeng J., Anh Phan C., Matsui Y. The impact of hard and soft quality management on quality and innovation performance: An empirical study. International Journal of Production Economics, 2015, 162: 216-226.

42. Zhang D., Linderman K., Schroeder R. G. The moderating role of contextual factors on quality management practices. Journal of Operations Management, 2012, 30 (1-2):12-23.

43. Zu X., Fredendall L. D., Douglas T. J. The evolving theory of quality management: The role of Six Sigma. Journal of Operations Management, 2008, 26 (5):630-650.

\section{Figures}

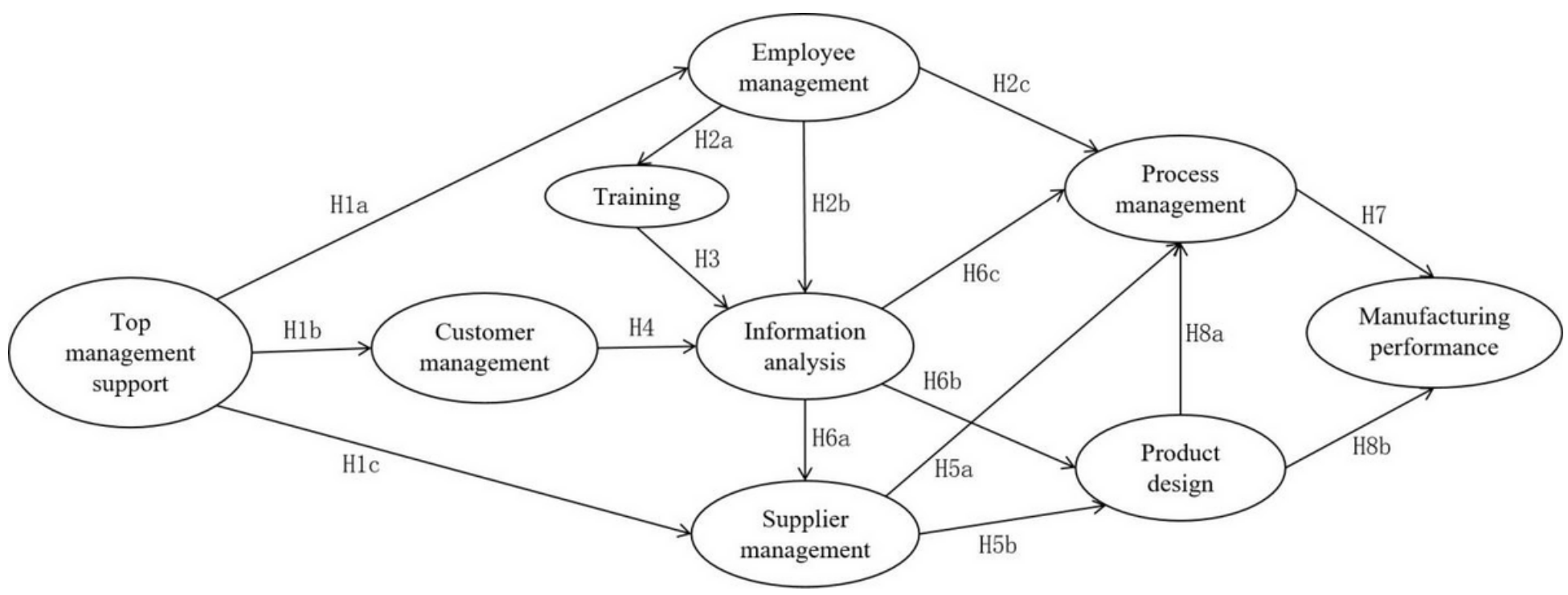

Figure 1

Theoretical model 


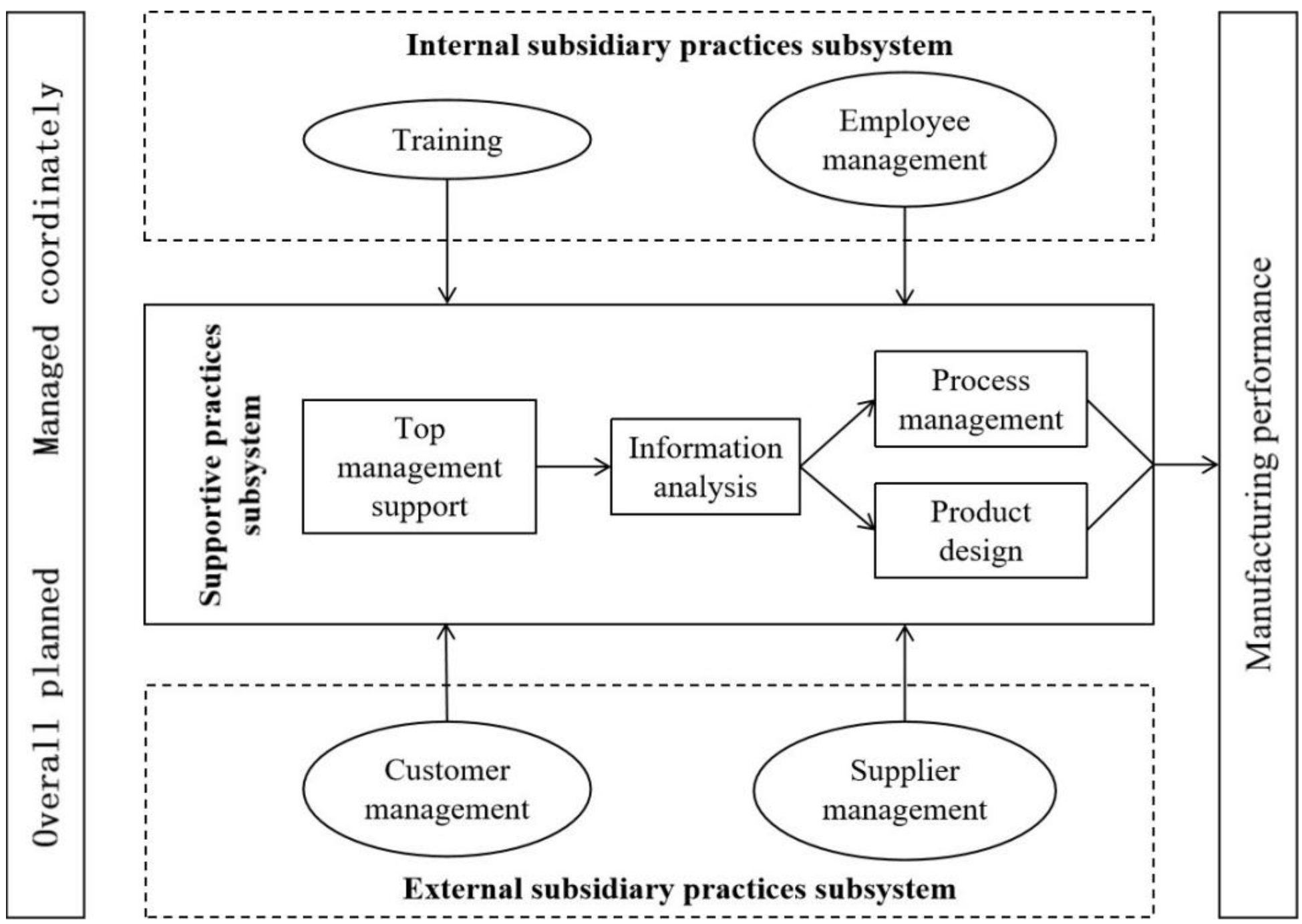

Figure 2

Synergistic model of quality management practice 